\title{
Cutaneous Vasculitis and Generalized Lymphadenopathy Associated with Extended- Spectrum Beta-Lactamase (ESBL)-Producing Escherichia coli Endocarditis: A Rare Case Report
}

\author{
Aninka Saboe (D) - Minsy T. Sari · Charlotte J. Cool - Badai B. Tiksnadi • \\ Laniyati Hamijoyo · Leonardus Widyatmoko · Rama Nusjirwan • \\ Arto Y. Soeroto
}

Received: October 11, 2020 / Accepted: November 24, 2020 / Published online: December 7, 2020

(C) The Author(s) 2020

\section{ABSTRACT}

Introduction: Infective endocarditis (IE) has been known as the great imitator due to variable clinical manifestation, making its diagnosis challenging. A missed diagnosis could lead to inappropriate therapy. We presented a rare case of blood culture-negative infective endocarditis (BCNIE) due to extended-spectrum beta-lactamase (ESBL)-producing Escherichia coli manifest with cutaneous vasculitis and generalized lymphadenopathy. We highlighted its diagnostic challenge and management.

Case Illustration and Discussion: A 36-year-old male with known asymptomatic ruptured sinus of

A. Saboe $(\varangle) \cdot$ M. T. Sari · C. J. Cool · B. B. Tiksnadi Department of Cardiology and Vascular Medicine, Universitas Padjadjaran, Dr. Hasan Sadikin General Hospital, Bandung, Indonesia

e-mail: aninka.saboe@unpad.ac.id

L. Hamijoyo · A. Y. Soeroto

Department of Internal Medicine, Universitas Padjadjaran, Dr. Hasan Sadikin General Hospital, Bandung, Indonesia

L. Widyatmoko

Clinical Microbiology Division, Department of Clinical Pathology, Universitas Padjadjaran, Dr. Hasan Sadikin General Hospital, Bandung, Indonesia

R. Nusjirwan

Cardiothoracic Surgery Division, Department of Surgery, Universitas Padjadjaran, Dr. Hasan Sadikin General Hospital, Bandung, Indonesia
Valsalva (SOV) presented with fever of unknown origin for six months, fatigue, weight loss with a history of multiple hospitalizations. The physical examination revealed a continuous murmur at Erb's point, cutaneous vasculitis, and bilateral inguinal lymphadenopathy. The laboratory result was leukocytosis and elevated C-Reactive Protein (CRP). Generalized lymphadenopathy was detected from the thorax and abdominal Computed Tomography (CT) Scans. Positive Anti Nuclear Antibody (ANA) Indirect Immunofluorescence (IF) speckled pattern led us to consider an autoimmune as the etiology, but we still considered IE as a differential diagnosis due to history of structural heart disease. Detection of multiple tiny oscillating masses at the tricuspid valve from the echocardiogram and cardiac CT led to possible IE diagnosis. Negative three consecutive blood cultures led the diagnosis to BCNIE. Surgery was performed to evacuate the vegetations, repair the SOV, and tricuspid valve replacement with a bioprosthetic valve. These results in improvement of the patient's condition. ESBL-producing Escherichia coli yielded in tissue culture made the diagnosis of IE became definite.

Conclusion: ESBL-producing Escherichia coli should be considered as the etiology of BCNIE. Cutaneous vasculitis and generalized lymphadenopathy as a manifestation of IE could lead to diagnostic confusion. A thorough investigation will help clinician to avoid delay or inappropriate treatment that could be detrimental for the patient. 
Keywords: Blood culture-negative infective endocarditis; Case report; Cutaneous vasculitis; ESBL-producing escherichia coli; Lymphadenopathy

\section{Key Summary Points}

\section{Why carry out this study?}

Diagnostic and management of infective endocarditis remain challenging despite medical advances.

We described a rare case report of blood culture-negative infective endocarditis (BCNIE) due to Extended-Spectrum BetaLactamase (ESBL)-producing Escherichia coli endocarditis manifest with cutaneous vasculitis and generalized lymphadenopathy.

\section{What was learned from the study?}

ESBL-producing Escherichia coli could be a cause of BCNIE.

ESBL-producing Escherichia coli

Endocarditis should be considered as an etiology of prolonged fever manifest with cutaneous vasculitis and generalized lymphadenopathy.

Identification of the etiology of BCNIE will result in appropriate treatment and a favorable outcome.

Judicious antibiotic usage will reduce this emerging multi-resistance bacteria.

\section{DIGITAL FEATURES}

This article is published with digital features to facilitate understanding of the article. You can access the digital features on the article's associated Figshare page. To view digital features for this article go to https://doi.org/10.6084/m9. figshare.13280468.

\section{INTRODUCTION}

Despite diagnostic and therapeutic advances, infective endocarditis (IE) is still a challenging disease. The estimated incidence of IE is $3-10$ per 100.000 population [1]. This endocardial infection can have numerous signs and symptoms. Typically, they include fever, chills, and a heart murmur. Sometimes, the embolic complications occur as neurologic deficits, arthralgia, or vasculitis could lead to the diagnosis of IE [2].

IE as a cause of vasculitis is relatively uncommon; A study from Blanco et al. showed that only less than $1 \%$ of patients had vasculitis associated with IE [2]. Conversely, many autoimmune diseases can mimic IE. It is essential to differentiate these two different disease etiologies due to similarities of the symptoms and diagnostic panels [2]. Generalized lymphadenopathy is defined as abnormal enlargement of two or more noncontiguous lymph node regions. It can be caused by infection, autoimmune, medication, or malignancy [3]. Escherichia coli is a rare cause of IE, count approximately $0.51 \%$ of IE cases [4].

We described a rare case report of blood culture-negative infective endocarditis (BCNIE) in the ruptured sinus of Valsalva (SOV) due to extended-spectrum beta-lactamase (ESBL)-producing Escherichia coli associated with vasculitis and generalized lymphadenopathy. We emphasized its diagnostic challenge and management.

This study was conducted following the 1964 Declaration of Helsinki and its subsequent amendments.

We have obtained the patient's consent to publish the clinical data, including the images.

\section{CASE REPORT}

\section{Patient Information}

A 36-year-old male, with a history of asymptomatic ruptured SOV since five years ago, presented to our hospital with prolonged fever, fatigue, and weight loss for six months. The patient had a history of multiple 
hospitalizations and prior antibiotic usage. The patient had good oral hygiene and no signs of infection in the upper respiratory tract, urinary tract, or gastrointestinal tract; neither history of intravenous (IV) drug abuse.

\section{Clinical Findings}

The remarkable physical examinations were anemic conjunctiva, continuous murmur at Erb's point, hepatosplenomegaly, bilateral inguinal lymphadenopathy, and petechial rashes distributed over the extremities and upper trunk (Fig. 1).

\section{Diagnostic Assessment}

Laboratory results showed hemoglobin $7.8 \mathrm{gr} /$ $\mathrm{dl}$, leucocytosis 15.400/uL, thrombocyte 154.000/uL, elevated C-Reactive Protein (CRP) $6.3 \mathrm{mg} / \mathrm{dl}$, negative three consecutive blood culture, normal urine, and feces analysis. The Anti Nuclear Antibody (ANA) Indirect Immunofluorescence (IF) speckled pattern (weak positive), and positive Anti Proliferating Cell Nuclear Antigen (Anti-PCNA) test. Thorax and abdominal Computed Tomography (CT) Scans detected multiple lymphadenopathy at bilateral paratracheal superior, subcarinal, bilateral hilar, left inferior paratracheal, mesenteric, and bilateral inguinal regions

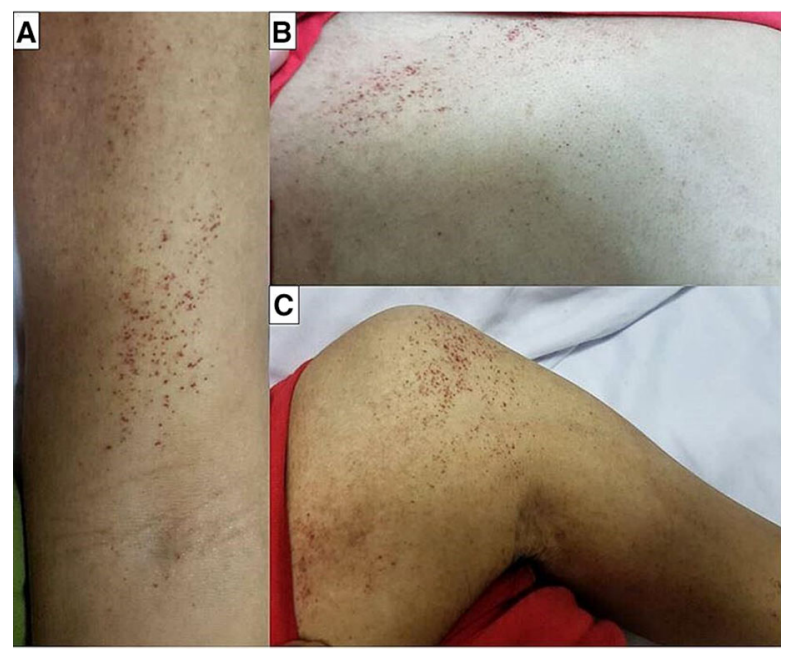

Fig. 1 Widespread petechiae at a upper extremities; b upper trunk; c knee represented cutaneous vasculitis
(Fig. 2). Transthoracic echocardiography (TTE) revealed the ruptured SOV but did not find any vegetation. Due to inconclusive findings from TTE, we proceed to transesophageal echocardiography (TEE) and CT cardiac, which showed multiple small vegetations attached to the leaflet of tricuspid valve with chordal rupture (Figs. 3 and 4). These findings led to the diagnosis of BCNIE.

\section{Therapeutic Intervention}

The patient was given empiric antibiotic therapy with ampicillin sulbactam $4 \times 3 \mathrm{~g}$ IV and gentamicin $1 \times 160 \mathrm{mg}$ IV for one month. However, even after the therapy, as mentioned earlier, the fever persisted and repeated three consecutive blood cultures remained negative. Therefore, we decided to perform cardiac surgery to evacuate the vegetation and repaired the ruptured SOV.

Intraoperative, we found ruptured SOV and multiple small vegetations that attached to the tricuspid valve leaflets (Fig. 5). The pathology examination of the valve revealed acute and chronic infection with polymorphonuclear and mononuclear cell infiltration. The clustered rod-shaped bacterias were also visualized (Fig. 6). The culture from the valve yielded ESBL-Producing Escherichia coli, hence making the diagnosis of IE became definite.

\section{Follow-up and Outcomes}

The antibiotic was given according to culture and resistance profile. The resistance test showed multiple resistance to most of the $\beta$ lactamase inhibitors, including ampicillin/sulbactam, ceftriaxone, piperacillin/tazobactam, cefotaxime, ceftazidime, cefepime, aztreonam but sensitive to meropenem. Hence, meropenem was given for another four weeks. The fever and cutaneous vasculitis were no longer detected, and the patient was discharged from the hospital. Six months later, the patient is completely asymptomatic, and the inguinal lymph node is no longer palpable. (Timeline of the patient's medical history, present illness, treatment, and the outcome is in Fig. 7). 


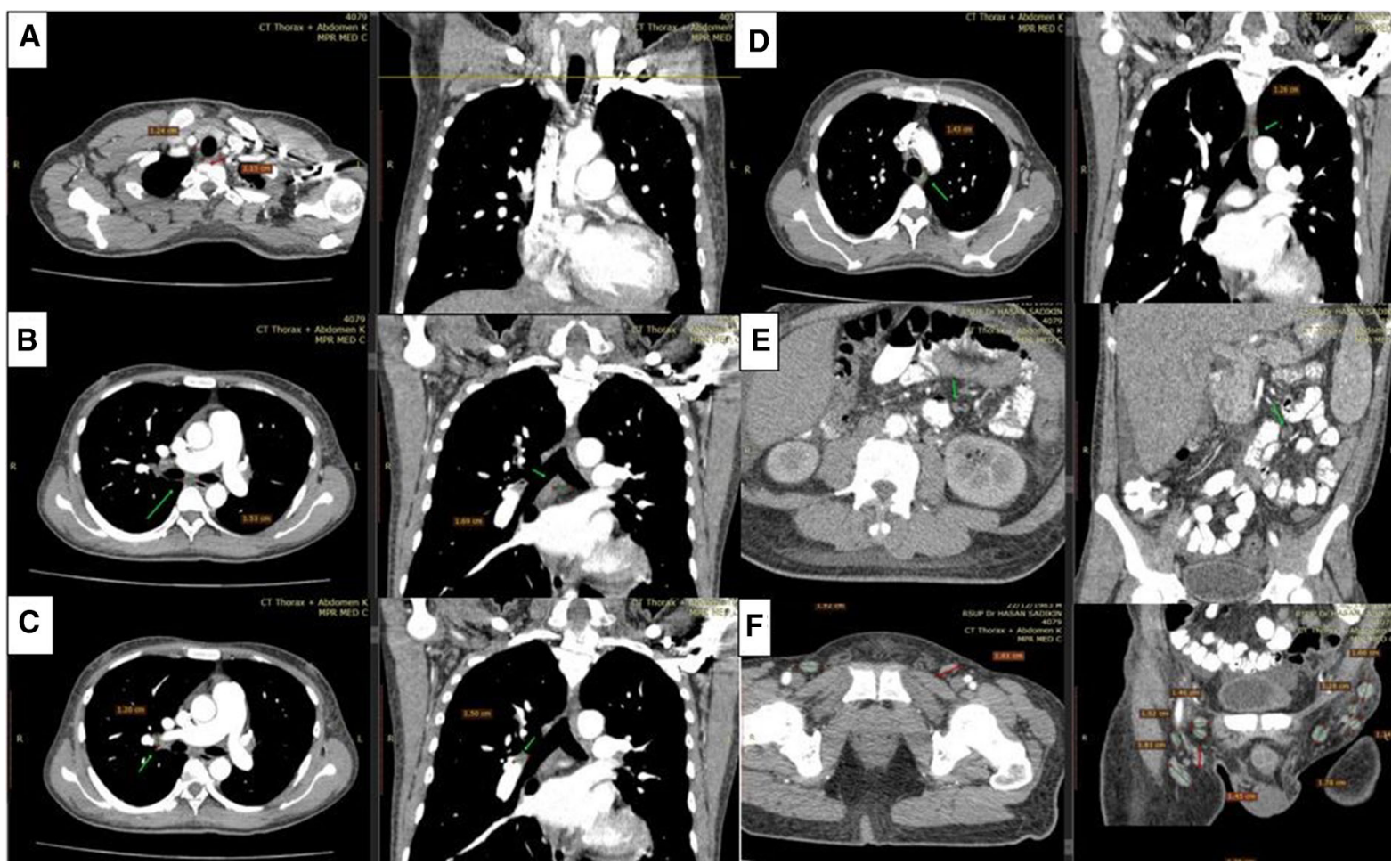

Fig. 2 Multiple lymphadenopathies detected from thorax and abdomen CT Scans: a paratracheal superior bilateral; b subcarinal; c hilar bilateral; $\mathbf{d}$ left inferior paratracheal; e mesenteric; $\mathbf{f}$ inguinal bilateral (lymph node showed by arrow)

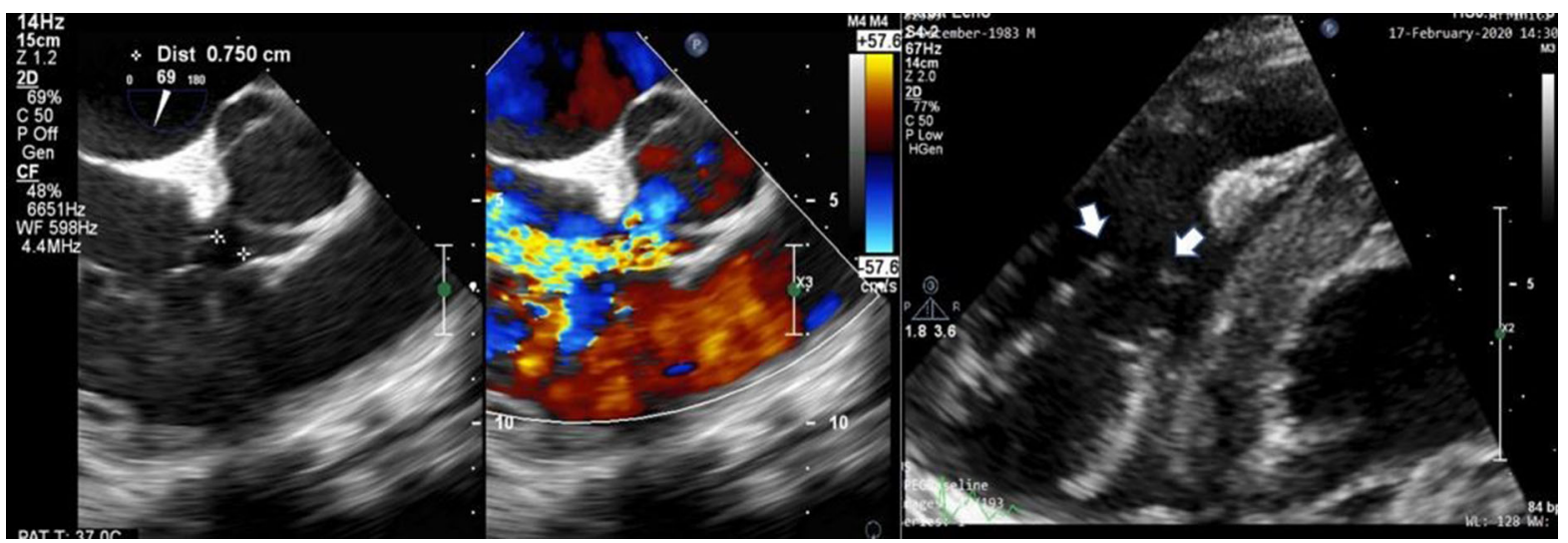

Fig. 3 Echocardiography showed ruptured sinus of Valsalva right coronary cups (RCC) to the right atrium (RA) sized 7.5 $\mathrm{mm}$ (left picture) and multiple small vegetations attached to the tricuspid valve (the right image showed by arrow)

\section{DISCUSSION}

Fever of unknown origin (FUO) is characterized as a temperature higher than $38.3^{\circ} \mathrm{C}$ for at least three weeks and unclear diagnosis after one week of hospital investigation. Three major categories of illness account for the "classic"
FUO cases are infections, connective tissue diseases, and malignancies [5].

IE is one of the most reported etiology in FUO. Although variable clinical presentations, fever remains the most frequently reported symptoms (up to 80\%-90\%) for IE. Typically, it is associated with constitutional symptoms. 


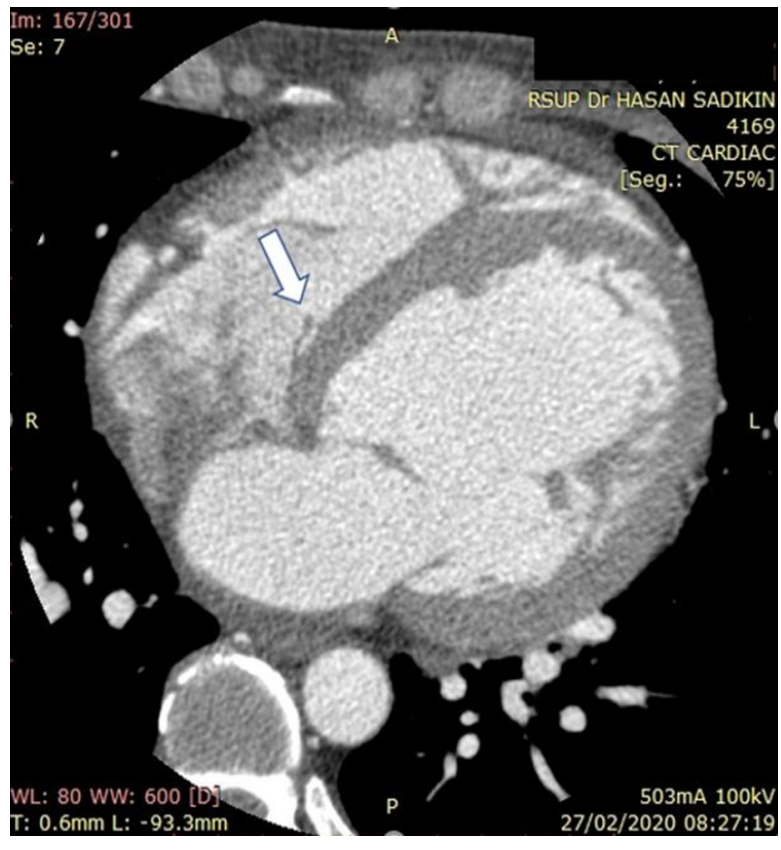

Fig. 4 Vegetation at the tricuspid valve (arrow) visualized from cardiac CT Scan

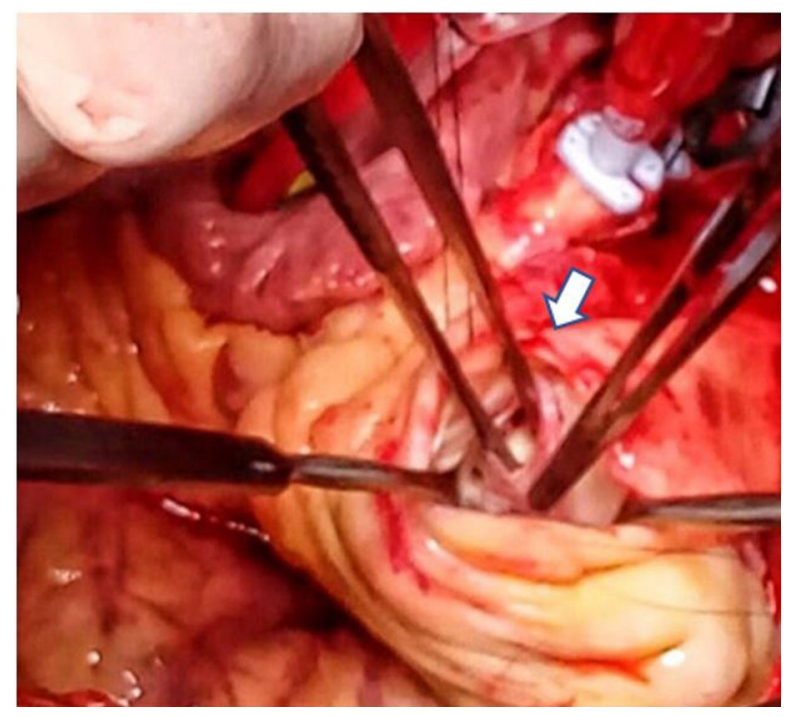

Fig. 5 Ruptured sinus of Valsalva from right coronary cups (RCC) to the right atrium (RA) sized $9 \mathrm{~mm}$ (arrow)

Splenomegaly and rarely lymphadenopathy can be found. Cardiac murmur often heard suggest preexisting cardiac condition or as a complication of IE [5].

Ruptured SOV is an uncommon cardiac lesion, mainly due to sinuses dilatation and aneurysm. It can occur as a congenital or acquired disease. The etiology may be due to a defect in the media layer within the aortic valve's annulus fibrosus and aorta, atherosclerosis, trauma, syphilis, IE, and collagen vascular disorders such as Marfan syndrome [6]. Our patient had five years of history asymptomatic ruptured SOV as a predisposing factor for IE. The presence of vasculitis and generalized lymphadenopathy with ANA IF speckled pattern (weakly positive), positive anti-PCNA test, and no vegetation detected earlier in transthoracic TTE initially made us consider autoimmune or malignancy as the etiology.

Vasculitis is a disease characterized by infiltration of inflammatory cells surrounding a vessel wall [7]. It can be associated with a diverse group of diseases. In general, the immunological mechanism mediates vasculitis. Clinically, vasculitis can be classified into systemic necrotizing vasculitis, giant cell vasculitis, vasculitis syndrome, or predominantly cutaneous small-vessel vasculitis [8]. Our patient presented with multiple petechial rashes, and normal platelet counts consistent with cutaneous small-vessel vasculitis.

Cutaneous small-vessel vasculitis is classified as idiopathic or secondary due to infection, drugs, connective tissue disease, malignancy, or other diseases. The etiology of secondary vasculitis is challenging to differentiate due to the same cellular component in histology [8]. Additionally, antibodies as autoimmune markers may become positive in infection $[2,10]$. A study from Blanco, et al. found that bacterial endocarditis was the etiology in 6 cases from 766 patients with cutaneous vasculitis. Histological findings of endocarditis-associated cutaneous vasculitis are characterized by leukocytoclastic vasculitis caused by micro-emboli and immune complex deposition on the vascular endothelium [2, 8]. The vasculitis is more commonly associated with subacute than acute IE, because in chronic inflammation, the antigen and antibodies' level is markedly increased despite the negative blood culture [8]. These pathomechanism could explain the manifestation of the vascular phenomenon in our patient. 


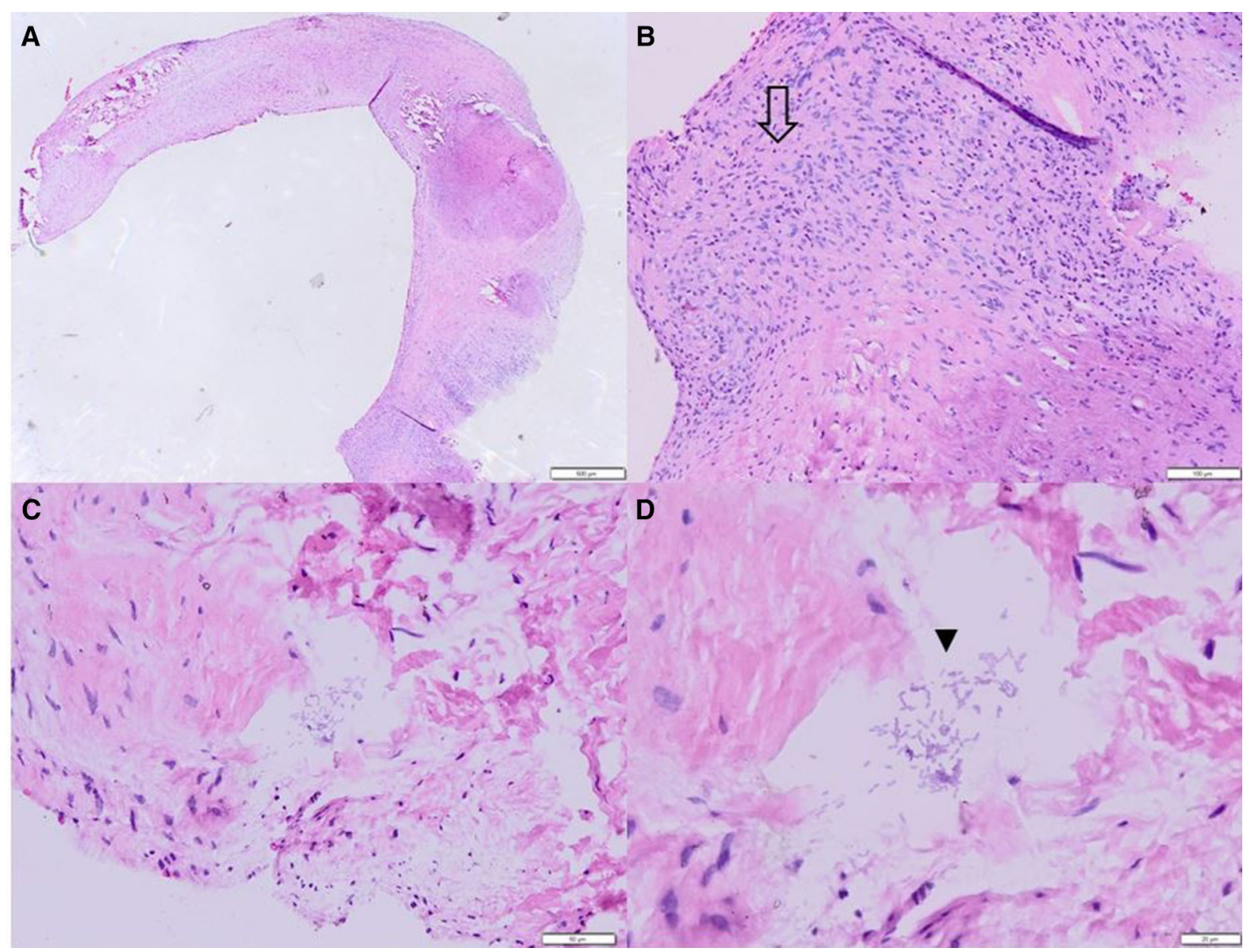

Fig. 6 Pathology examination of the tricuspid valve (a) revealed polymorphonuclear (PMN) and mononuclear cells (MN) infiltration (b) (arrow) represented acute and

Immunosuppression is the recommended therapy in most types of vasculitis. However, misdiagnosing a case of bacterial endocarditis as an autoimmune condition and initiating the immunosuppressive therapy could be fatal [2]. Hence, patients with cutaneous vasculitis should be assessed carefully for bacterial infections, especially if associated with fever, constitutional symptoms, signs of focal infection, and raised inflammatory biomarkers [2, 9]. We exclude autoimmune as the cause of this patient due to unsuitable clinical features with normal rheumatoid factor and C3 complement results.

Our patient clinically fulfilled the modified Duke criteria for endocarditis with one major criterion (imaging positive for IE) and three minor criteria (predisposing heart condition, chronic infections; Clustered rod-shaped bacteria also visualized (c) and the closer look (d) ( $\mathbf{\nabla}$ triangle)

fever, and vascular phenomenon) [11]. Traditionally, TTE is sufficient to visualize cardiac structures. However, if the TTE is negative or equivocal, it may be reasonable to pursue TEE and cardiac CT as in our case [12].

Our patient was diagnosed as BCNIE due to three consecutive blood sampling, and repeated culture after empirical therapy remained negative. A Study by Werner, et al. found that $20 \%$ of 820 cases of confirmed IE had negative blood culture. There are several causes for BCNIE, such as sterilized blood culture by previous antibiotic treatment, fastidious organisms requiring prolonged incubation, true blood culture-negative IE due to intracellular bacteria and non-infectious causes [13]. Pierre, et al. identified the causative organism in 348 cases of BCNIE, 


\begin{tabular}{|c|c|c|c|c|c|c|c|c|c|c|}
\hline $\begin{array}{l}5 \text { years } \\
\text { before } \\
\text { admission }\end{array}$ & $\begin{array}{l}6 \text { months } \\
\text { before } \\
\text { admission }\end{array}$ & $\begin{array}{l}5 \text { months } \\
\text { before } \\
\text { admission }\end{array}$ & $\begin{array}{l}4 \text { months } \\
\text { before } \\
\text { admission }\end{array}$ & $\begin{array}{l}3 \text { months } \\
\text { before } \\
\text { admission }\end{array}$ & $\begin{array}{l}1 \text { month before } \\
\text { admission }\end{array}$ & $\begin{array}{l}\text { Admitted to our } \\
\text { hospital }\end{array}$ & $\begin{array}{l}1 \text { month after } \\
\text { empiric IE } \\
\text { treatment }\end{array}$ & $\begin{array}{l}\text { Post } \\
\text { operative } \\
\text { management }\end{array}$ & Discharge & \begin{tabular}{|l|}
6 months \\
Follow-up
\end{tabular} \\
\hline $\begin{array}{l}\text { - Asymptomatic } \\
\text { ruptured SOV }\end{array}$ & $\begin{array}{l}\text { - Onset of } \\
\text { fever and } \\
\text { admitted to } \\
\text { private } \\
\text { hospital, } \\
\text { considered } \\
\text { diagnosed } \\
\text { as typhoid } \\
\text { fever } \rightarrow \\
\text { given } \\
\text { antibiotic for } \\
\text { typhoid } \\
\text { - No blood } \\
\text { culture was } \\
\text { taken }\end{array}$ & $\begin{array}{l}\text { - Readmitted } \\
\text { to the } \\
\text { same } \\
\text { hospital } \\
\text { due to } \\
\text { recurrent } \\
\text { fever; } \\
\text { - Blood } \\
\text { culture } \\
\text { came out } \\
\text { negative; } \\
\text { - TTE was } \\
\text { done but } \\
\text { no } \\
\text { vegetations } \\
\text { was } \\
\text { detected; } \\
\text { - Suggest to } \\
\text { do TEE but } \\
\text { the patient } \\
\text { refused }\end{array}$ & $\begin{array}{l}\text { - Re- } \\
\text { hospitalized } \\
\text { due to fever } \\
\text { and } \\
\text { considered } \\
\text { diagnosed } \\
\text { as UTI } \\
\text { - No urine } \\
\text { culture was } \\
\text { done } \\
\text { - Treated } \\
\text { with empiric } \\
\text { antibiotic }\end{array}$ & $\begin{array}{l}\text { - Fever and } \\
\text { visit the } \\
\text { outpatient } \\
\text { department: } \\
\text { chest } x \text {-ray } \\
\overrightarrow{\text { suspected }} \\
\text { as lung } \\
\text { tuberculosis } \\
\text { with } \\
\text { negative } \\
\text { AFB } \\
\text { - Empirical } \\
\text { treatment } \\
\text { with oral } \\
\text { anti-TB }\end{array}$ & $\begin{array}{l}\text { - Fever despite } \\
\text { on oral anti-TB } \\
\text { and geneXpert } \\
\text { MTB came out } \\
\text { negative } \rightarrow \\
\text { the oral anti- } \\
\text { TB wass } \\
\text { discontinued } \\
\text { - Suspect } \\
\text { autoimmune } \\
\text { disease with: } \\
\text { - ANA panel } \\
\text { test: positive } \\
\text { anti PCNA } \\
\text { ANA IF } \\
\text { speckled } \\
\text { pattern } \\
\text { weak } \\
\text { positive } \\
\text { - normal } \\
\text { rheumatoid } \\
\text { factor, C3 } \\
\text { complement, } \\
\text { and anti } \\
\text { CCP } \\
\text { antibody }\end{array}$ & $\begin{array}{l}\text { - Fever, petechial } \\
\text { rashes distributed } \\
\text { over the extremities } \\
\text { and upper trunk, } \\
\text { lymphadenopathy at } \\
\text { inguinal } \\
\text { - Lab: } \\
\text { - Hb: } 7.8 \text { gr/dl } \\
\text { - WBC: } 15.400 / \mathrm{LL} \\
\text { - Platelet: } \\
154.000 / \mathrm{uL} \\
\text { - CRP: } 6.3 \mathrm{mg} / \mathrm{dl} \\
\text { - Normal urine and } \\
\text { feces analysis } \\
\text { - Negative } 3 \\
\text { consecutive blood } \\
\text { culture } \\
\text { TTE, TEE and } \\
\text { Cardiac CT Scan: } \\
\text { ruptured sinus of } \\
\text { Valsalva (RCC to } \\
\text { RA), suspect } \\
\text { multiple small } \\
\text { vegetations } \\
\text { attached to tricuspid } \\
\text { valve } \\
\text { - Bone marrow } \\
\text { biops: } \\
\text { erythropoiesis } \\
\text { hyperplasia } \\
\text { Thorax and } \\
\text { Abdominal CT } \\
\text { Scans: multiple } \\
\text { lymphadenopathies } \\
\text { Diagnosed as BCNIE }\end{array}$ & $\begin{array}{l}\text { - Fever } \\
\text { persisted } \\
\text { - Repeated } \\
3 \text { set of } \\
\text { blood } \\
\text { culture } \\
\text { remained } \\
\text { negative } \\
\text { - Decision to } \\
\text { performed } \\
\text { surgery to } \\
\text { evacuate } \\
\text { the } \\
\text { vegetations } \\
\text { and repair } \\
\text { ruptured } \\
\text { Sov }\end{array}$ & $\begin{array}{l}\text { - Pathological } \\
\text { examination } \\
\text { of the } \\
\text { vegetations } \\
\rightarrow \text { PMN and } \\
\text { MN cells } \\
\text { infiltrations } \\
\text { - Vegetations } \\
\text { culture: } \\
\text { ESBL- } \\
\text { producing } \\
\text { Escherichis } \\
\text { coli } \\
\text { sensitive to } \\
\text { Meropenem } \\
\text { - Meropenem } \\
\text { was given } \\
\text { for four } \\
\text { weeks }\end{array}$ & $\begin{array}{l}\text { - The fever } \\
\text { and } \\
\text { petechial } \\
\text { rashes } \\
\text { diminished }\end{array}$ & \begin{tabular}{|l} 
- No more \\
recurrent \\
fever, no \\
palpable \\
inguinal \\
lymph \\
node \\
- Good \\
prosthetic \\
valve \\
function
\end{tabular} \\
\hline
\end{tabular}

Fig. 7 Timeline of the patient's medical history, present illness, treatment, and outcome

which Escherichia coli as a causative etiology only in one case [14]. Since the causative agent in our case was supposed to be a culturable microorganism, there were several possible explanations as to why the culture in our case was sterile. Most IEs, especially acute onset patients, would show a positive blood culture that represents continuous bacteremia. Nevertheless, for subacute IE, as in our case, the blood culture frequently came out sterile because the bacteremia is usually "low-grade", with only up to 10 colony-forming units (CFU) per milliliter of venous blood, which makes it difficult to detect, especially when inadequate volume or set of blood samples are taken. The second most common cause of negative blood culture is the previous antibiotic treatment, as in our case. The use of antibiotics will inhibit the growth of microorganisms in the culture media and clear the planktonic form of the bacteria in the circulation while leaving the unculturable bacteria in the form of biofilm. Moreover, even in the untreated patient, blood culture is not always $100 \%$ positive because the microorganism can be located underneath the vegetation's fibrin layer, hence undetected from the circulation. However, the valve damage and low grade of inflammation are sustained $[15,16]$.

BCNIE is always challenging in management [13]. Due to the limited availability of the serology test in our hospital, we could not workup further. European Society of Cardiology (ESC) 2015 guidelines and American Heart Association 2014 guidelines for infective endocarditis stated that persistent bacteremia or fever $>7$ days despite adequate antibiotic treatment is considered class IIa and is eligible for early surgical intervention before discharge $[11,17]$. Due to the negative culture, we were unable to give an appropriate antibiotic treatment. After one month of empiric antibiotic therapy, the fever and vasculitis remained persistent, indicating ongoing infection and inflammation. Although the repeated three consecutive blood cultures remained negative, we decided to perform surgery to evacuate the vegetations and repair the ruptured SOV.

Culture from the vegetation yielded Escherichia coli. In a study from Morpeth, et al. Escherichia coli accounts for $30 \%$ of 49 non- 
HACEK gram-negative endocarditis cases [18]. Escherichia coli endocarditis is uncommon and mostly affects older women. The most frequent source of infection in Escherichia coli endocarditis is urinary tract infection. Data from the International Collaboration on EndocarditisProspective Cohort Study (ICE-PCS) found the infection source was unclear in $48 \%$ of patients, as in our case. Studies have discovered that extra-intestinal pathogenic Escherichia coli with highly distribute phylogenetic type $\mathrm{B} 2$ as a causative strain. The low incidence of the infection is due to poorly adherent to the endocardium. However, they have plenty of extra-intestinal virulence factors such as iron acquisition mechanism (aerobactin), the capability to escape host defense (capsule or $\mathrm{O}$-specific antigen), adhesins (P and S fimbriae), and toxin (hemolysin), which make them serious pathogen once they gain access into the extra-intestinal site $[4,19,20]$. Unfortunately, our center could not perform further analysis using multilocus sequence typing (MLST) to determine the virulence factors. However, based on phenotypic resistance analysis using Advanced Expert System VITEK 2 Software, we concluded that this is an ESBL production isolate, which is resistant to a variety of $\beta$-lactamase inhibitors. This emergence of multidrugresistant Escherichia coli is increasingly reported as the etiology of various infections, including IE [21-23]. Study from Ebbing, et al. found that ESBL-producing Escherichia coli infection was associated with significantly longer hospital stay duration and greater hospital charges [24].

The association between Escherichia coli infection and vasculitis, although rare, had been reported by several studies. Kain et al. found in vitro study in rats that Escherichia coli could activate neutrophils and damage human microvascular endothelium due to cross-reactive autoimmunity to a lysosomal membrane protein 2 (LAMP-2), hence cause pauci-immune focal necrotizing glomerulonephritis [25]. In the second case, Gayatri et al. found Escherichia coli associated with severe urticarial vasculitis. The pathogenesis may be through complex immune injury, septic emboli, or bacterial seeding that causes vascular necrosis [26].
Generalized lymphadenopathy may be a clue for systemic diseases such as infectious mononucleosis, sarcoidosis, mycobacterial infection, HIV, systemic lupus erythematosus, medication, and lymphoma. It is rarely caused by IE [27]. Few bacteria such as Bartonella sp. and Tropheryma whipplei have been reported to cause lymphadenopathy and IE $[28,29]$. The biopsy from the lymph node revealed reactive hyperplasia and direct microorganism invasion in these cases [30, 31]. Stuart, et al. found a case of transient hilar lymphadenopathy and tricuspid endocarditis due to Staphylococcus aureus. The possible mechanism is the reticuloendothelial system clearing the bacteria in the pulmonary vascular bed in addition to a probable cause of a metastatic pulmonic inoculation [32]. A study from Weist about gut bacterial translocation discovered increased of Escherichia coli CFU in mesenteric lymph node (MLN's) due to decreased bacteria elimination rate [33]. We presumed the generalized lymphadenopathy in our case was due to gut translocation of Escherichia coli through MLN's.

Based on our knowledge, this is the first case report of Escherichia coli endocarditis associated with cutaneous vasculitis and generalized lymphadenopathy. Escherichia coli endocarditis poses a poor outcome with regard to frequent complications. The mortality rate varies between studies, ranging from $16 \%$ to $64 \%$; $[18,34-36]$ Due to limited cases, there is no uniformity in the management, but the most common indications for surgery are refractory heart failure, large vegetation, embolization, intracardiac complication, and persistent bacteremia [34].

\section{Strengths}

We performed surgery for vegetation evacuation, pathological examination, and valve culture; hence, the Escherichia coli endocarditis diagnosis became definite.

\section{Limitations}

We did not perform skin and lymph node biopsy. Unfortunately, we did not perform MLST analysis for Escherichia coli either. 


\section{CONCLUSIONS}

The physician should recognize that although rare, ESBL-Producing Escherichia coli could cause blood culture-negative infective endocarditis associated with cutaneous vasculitis and generalized lymphadenopathy. Aggressive antibiotic and early surgical intervention for persistent infection are vital to improving patient survival. The presence of cutaneous vasculitis should be carefully evaluated for the underlying etiology since delay and inappropriate treatment could be fatal.

\section{Learning Points}

ESBL-Producing Escherichia coli endocarditis should be considered as an etiology of prolonged fever manifest with cutaneous vasculitis and generalized lymphadenopathy. Judicious antibiotic usage will reduce these emerging multi-resistance bacteria. Identification of the etiology of BCNIE will result in appropriate treatment and a favorable outcome.

\section{ACKNOWLEDGEMENTS}

We would like to express our sincere gratitude towards the participants of the study. Melawati Hasan, MD for obtaining the echocardiography images; R. Nuraini Yasmin K, MD and Astri Astuti, MD for helping with Cardiac CT interpretation; H. P. Dharmadji, MD for contributing in the case management; A. Fauzi Yahya, MD for supervising the case management.

Funding. We received neither funding nor sponsorship for this study nor any publication of this article. The authors funded the Rapid Service Fee.

Authorship. All named authors meet the International Committee of Medical Journal Editors (ICMJE) criteria for authorship for this article, take responsibility for the integrity of the work as a whole, and have given their approval for this version to be published.
Author Contributions. Aninka Saboe: Conceptualization, data curation, Writing-Original draft, review \& editing, supervision. Minsy Titi Sari: Conceptualization, Writing-Original draft, data curation. Badai Bhatara Tiksnadi: Conceptualization, data curation, review \& editing. Laniyati Hamijoyo: Writing - review \& editing. Leonardus Widyatmoko: Writing - review \& editing. Rama Nusjirwan: Writing - review \& editing. Arto Yuwono Soeroto: Writing - review $\&$ editing.

Disclosures. Aninka Saboe, Minsy T. Sari, Charlotte J. Cool, Badai B. Tiksnadi, Laniyati Hamijoyo, Leonardus Widyatmoko, Rama Nusjirwan and Arto Y. Soeroto have nothing to disclose.

Compliance with Ethics Guideline. This study was conducted following the 1964 Declaration of Helsinki and its subsequent amendments. We have obtained the patient's consent to publish the clinical data, including the images.

Data Availability. Data sharing is not available in this article, as no new datasets were generated during the current study.

Open Access. This article is licensed under a Creative Commons Attribution-NonCommercial 4.0 International License, which permits any non-commercial use, sharing, adaptation, distribution and reproduction in any medium or format, as long as you give appropriate credit to the original author(s) and the source, provide a link to the Creative Commons licence, and indicate if changes were made. The images or other third party material in this article are included in the article's Creative Commons licence, unless indicated otherwise in a credit line to the material. If material is not included in the article's Creative Commons licence and your intended use is not permitted by statutory regulation or exceeds the permitted use, you will need to obtain permission directly from the copyright holder. To view a copy of this licence, visit http:// creativecommons.org/licenses/by-nc/4.0/. 


\section{REFERENCES}

1. Khan O, Shafi AMA, Timmis A. International guideline changes and the incidence of infective endocarditis: a systemic review. Open Heart. 2016;3:e000498. https://doi.org/10.1136/openhrt2016-000498.

2. Loricera, J., Loricera, J., Hernandez, J. L., et al. Cutaneous vasculitis associated with severe bacterial infections. A study of 27 patients from a series of 766 cutaneous vasculitis. Clin Exp Rheumatol. 2015;33(2 Suppl 89):S-26-43. Available at: https:// www.clinexprheumatol.org/article.asp? $\mathrm{a}=8529$

3. Freeman AM, Matto P. Adenopathy. StatPearls [Internet]. Treasure Island (FL): StatPearls Publishing; 2020. Available from: https://www.ncbi.nlm.nih. gov/books/NBK513250/

4. Akuzawa N, Kurabayashi M. Native valve endocarditis due to Escherichia coli infection: a case report and review of the literature. BMC Cardiovasc Disord. 2018;18:195. https://doi.org/10.1186/ s12872-018-0929-7.

5. Burzo ML, Antonelli M, Pecorini G, Favuzzi AMR, Landolfi R, Flex A. Fever of unknown origin and splenomegaly: A case report of blood culture-negative endocarditis. Medicine. 2017. https://doi.org/ 10.1097/MD.0000000000009197.

6. Moreel S, Dymarkowski S, Ridder AD. Ruptured sinus of valsalva a case report. Eur Cardiol Rev 2012; 8(12):139-41 https://doi.org/10.15420/ecr.2012.8.2. 139

7. Tous-Romero F, Delgado-Márquez AM, GargalloMoneva V, Zarco-Olivo C. Cutaneous vasculitis: a presentation with endocarditis to keep in mind. An Bras Dermatol. 2017;92(4):594-5.

8. Choucair J. Infectious Causes of Vasculitis. Intech. 2013. https://doi.org/10.5772/55189.

9. González-Juanatey C, González-Gay MA, Llorca J, et al. Rheumatic manifestations of infective endocarditis in non-addicts. A 12-year study. Medicine (Baltimore). 2001;80(1):9-19. https://doi.org/10. 1097/00005792-200101000-00002.

10. Tzang BS, Chen TY, Hsu TC, Liu YC, Tsay GJ. Presentation of autoantibody to proliferating cell nuclear antigen in patients with chronic hepatitis B and C virus infection. Ann Rheum Dis 1999; 58: 630-634. Available from: http://life.nthu.edu.tw/ $\sim$ lablyc/files/annals1999.pdf

11. Habib G, Lancelloti P, Antunes MJ, Bongiorni MG, et al. ESC Guidelines for the management of infective endocarditis. Eur Heart J. 2015. https:// doi.org/10.1093/eurheartj/ehv319.

12. Afonso L, Kottam A, Reddy V, Penumetcha A. Echocardiography in Infective Endocarditis: State of the Art. Curr Cardiol Rep. 2017;19:127. https://doi. org/10.1007/s11886-017-0928-9.

13. Ebato M. Blood culture-negative endocarditis. Intech Open. 2018. https://doi.org/10.5772/ intechopen.76767.

14. Houpikian P, Raoult D. Blood culture-negative endocarditis in a reference center: etiologic diagnosis of 348 cases. Medicine (Baltimore). 2005;84(3):162-73. https://doi.org/10.1097/01.md. 0000165658.82869 .17 .

15. Towns ML, Reller LB. Diagnostic methods current best practices and guidelines for isolation of bacteria and fungi in infective endocarditis. Infectious disease clinics of North America. 2002;16(2): 363-76, ix-x.

16. Olson ME, Ceri H, Morck DW, Buret AG, Read RR. Biofilm bacteria: formation and comparative susceptibility to antibiotics. Canadian journal of veterinary research $=$ Revue canadienne de recherche veterinaire. $2002 ; 66(2): 86-92$.

17. Werner M, Andersson R, Olaison L, Hogevik H. A Clinical study of cultured-negative endocarditis. Medicine (Baltimore). 2003;82(4):263-73. https:// doi.org/10.1097/01.md.0000085056.63483.d2.

18. Morpeth S, Murdoch D, Cabell $\mathrm{CH}$, et al. NonHACEK gram-negative bacillus endocarditis. Ann Intern Med. 2007;147(12):829-35. https://doi.org/ 10.7326/0003-4819-147-12-200712180-00002.

19. Micenková L, Bosak J, Vrba M, Ševčíková A, Šmajs D. Human extra-intestinal pathogenic Escherichia coli strains differ in prevalence of virulence factors, phylogroups, and bacteriocin determinants. BMC Microbiol. 2016;16:218. https://doi.org/10.1186/ s12866-016-0835-z.

20. Russo TA, Johnson JR. Proposal for a new inclusive designation for extra-intestinal pathogenic isolates of Escherichia coli: ExPEC. J Infect Dis. 2000;181: 1753-4. https://doi.org/10.1086/315418.

21. Alhashash F, Weston V, Diggle M, McNally A. Multidrug-resistant Escherichia coli bacteremia. Emerg Infect Dis. 2013;19(10):1699-701.

22. Gupta V, Rani H, Singla N, Kaistha N, Chander J. Determination of Extended-Spectrum $\beta$-Lactamases and AmpC Production in Uropathogenic Isolates of Escherichia coli and Susceptibility to Fosfomycin. J Labor Phys. 2013;5(2):90-3. 
23. Naha S, Naha K, Acharya V, Hande HM, Vivek G. Community-acquired multidrug-resistant Gramnegative bacterial infective endocarditis. BMJ Case Reports. 2014;2014:bcr2014204176.

24. Ebbing Lautenbach, Jean Baldus Patel, Warren B. Bilker, Paul H. Edelstein, Neil O. Fishman, Extended-Spectrum $\beta$-Lactamase-Producing Escherichia coli and Klebsiella pneumoniae: Risk Factors for Infection and Impact of Resistance on Outcomes, Clinical Infectious Diseases, 2001;32(8), 1162-1171, https://doi.org/10.1086/319757

25. Bosch X. LAMPs and NETs in the Pathogenesis of ANCA Vasculitis. J Am Soc Nephrol. 2009;20(8): 1654-6. https://doi.org/10.1681/ASN.2009060616.

26. Khatri G, Mahajan VK, Raina R. Escherichia coli: an uncommon cause of severe urticarial vasculitis. Dermatol Online. 2015;6(3):365-6. https://doi.org/ 10.7241/ourd.20153.99.

27. Ferrer, R. L. Evaluation of peripheral lymphadenopathy in adults. Up to date. 2018. Available from: https://www.uptodate.com/contents/ evaluation-of-peripheral-lymphadenopathy-inadults

28. Noopetch P, Ponpinit T, Suankratay C. Bartonella henselae infective endocarditis with dissemination: A case report and literature review in Southeast Asia. Elsevier. 2018. Available from https://doi.org/ 10.1016/j.idcr.2018.e00441

29. Fenollar F, Lepidi H, Raoult D. Whipple's Endocarditis: Review of the Literature and Comparisons with Q fever, Bartonella Infection, and Blood
Culture-Positive Endocarditis. Clin Infect Dis. 2001;33:1309-16. https://doi.org/10.1086/322666.

30. Holmes AH, Greenough TC, Balady GJ, et al. Bartonella Henselae Endocarditis in an Immunocompetent Adult. Clin Infect Dis 1995. 21(4): p 1004-007. Available at http://www.jstor.org/ stable/4458958.

31. Walters S, Valliani T, Przemioslo R, Rooney N. Whipple's disease: an unexpected finding in a peripheral lymph node biopsy. Lancet. 2014;383(9936):2268. https://doi.org/10.1016/ S0140-6736(14)61043-6.

32. Mirvis SE, Doyle KK, Diaconis JN. Transient hilar lymphadenopathy due to bacterial endocarditis. Chest J. 1986;89(3):461-2. https://doi.org/10.1378/ chest.89.3.461.

33. Weist R. Bacterial Translocation. Bioscience Microflora. 2005. 24(3): p61-90. Available at: https:// www.jstage.jst.go.jp/article/bifidus/24/3/24_3_61/_ pdf

34. Arunasalam S, Pickles R. Escherichia coli Endocarditis. Infect Dis Clin Practice. 2010;18(4):247-50. https://doi.org/10.1097/ipc.0b013e3181c753d1.

35. Micol R, Lortholary O, Jaureguy F, et al. Escherichia coli native valve endocarditis. Clin Microbiol Infect. 2006;12:401-3.

36. Branger S, Casalta JP, Habib G, et al. Escherichia coli endocarditis: seven new cases in adults and review of literature. Eur J Clin Microbiol Infect Dis. $2005 ; 24: 537-41$. 